\title{
MODALITAS DALAM TEKS BERITA HOAKS: KAJIAN LINGUISTIK SISTEMIK FUNGSIONAL
}

\author{
Firda Amrullah ${ }^{1}$, Abdul Hakim Yassi ${ }^{2}$, Gusnawaty Gusnawaty ${ }^{3}$ \\ ${ }^{1}$ Linguistic Department of Faculty Cultural Sciences, Hasanuddin University \\ ${ }^{2}$ English Language Department of Faculty Cultural Sciences, Hasanuddin University \\ ${ }^{3}$ Local Languages Department of Faculty Cultural Sciences, Hasanuddin University \\ 1effierda@unhas.ac.id \\ ${ }^{2}$ hakimyassi@yahoo.com \\ ${ }^{3}$ gusnawaty@fs.unhas.ac.id
}

\begin{abstract}
This study aimed to examine the use of modality in news text. This research expected to improve public media literacy in identifying hoax news through modality analysis. This research presented qualitative descriptive data with the systemic functional linguistic approach. This study focused on type, value, and modality orientation. The research data resource was Hoax Report of Legislative and President Election Internet Content Control Sub-directorate for August 2018 by Ministry of Communication and Information of Republic Indonesia. The research result showed that modality type possibility modalization intermediate degree and modality type obligation modulation intermediate degree to dominate other types of modality. Besides, this research didn't find the kinds of modality in hoax-text news. They were modality type of usuality modalization of medium degree and modality type of inclination modulation of low degree.
\end{abstract}

Keyword: Modality, hoax, systemic functional linguistics

\section{PENDAHULUAN}

Pesatnya perkembangan teknologi informasi dan komunikasi berkontribusi besar terhadap perkembangan media massa. Media massa konvensional dianggap tidak lagi mampu memenuhi kebutuhan masyarakat akan informasi terkini dari aspek kecepatan dan kemudahan mengakses kapan saja dan dimana saja yang menjadi tawaran media massa daring. Namun, tidak ada perubahan tanpa konseskuensi. Kecenderungan masyarakat akan kebutuhan informasi yang aktual dan faktual seolah menjadi bumerang bagi masyarakat sendiri. Seringkali berita yang disajikan media daring tidak lagi melalui proses penyuntingan yang ketat sehingga kebenaran informasi yang disajikan pun tidak dapat dipastikan. Bahkan, beberapa pihak, dengan sengaja menyebarkan berita hoaks untuk meraup keuntungan dari jumlah pengikut. Bukan hanya, keuntungan finansial yang melatarbelakangi penyebaran hoaks, kericuhan sebagai dampak provokasi berita hoaks juga menjadi kenikmatan tersendiri bagi penyebar berita hoaks. Media daring seolah kehilangan ideologinya. Padahal kostruksi dari setiap wacana yang disajikan oleh media massa memiliki muatan-muatan ideologis yang sangat bergantung pada dasar filosofis dari idealism (Fadhil, 2017).

Penyebaran hoaks di Indonesia dinilai telah melewati batasan dan meresahkan sehingga diperlukan tindakan sarius untuk menekan angka penyebaran berita hoaks yang terus bertambah. Aksi pemblokiran oleh Kementerian Komunikasi dan Informatika Republik Indonesia terhadap berit hoaks tidak mampu menandingi kecepatan penyebaran hoaks. Hal ini dikarenakan masyarakat secara tidak sadar menjadi sukarelawan dalam penyebaran berita hoaks sehingga 
yang diperlukan dalam menekan penyebaran berita hoaks adalah peningkatan literasi media bagi masyarakat.

Peningkatan literasi media bagi masyarakat terkait berita hoaks dapat dilakukan dengan meningkatkan pemahaman masyarakat tentang karakter berita hoaks agar masyarakat tidak dengan mudahnya meneruskan suatu informasi tanpa mengecek kebenarannya terlebih dahulu. Kemampuan mengidentifikasi berita hoaks dapat dilakukan dengan melihat penggunaan modalitasnya. Menurut (Halliday \& Matthiessen, 2014) modalitas menafsirkan wilayah ketidakpastian yang terletak antara 'ya ' dan 'tidak'. Dengan demikian, pemilihan modalitas menempatkan sikap atau posisi pembicara pada batasan antara polaritas positif dan negatif dalam mengungkapkan kebenaran dan aktualisasi peristiwa.

Penelitian ini dikaji dengan teori Linguistik Sistemik Fungsional (LSF) yang difokuskan pada pendekatan fungsi interpersonal. Modalitas merupakan realisasi makna interpersonal karena pembicara dapat memberikan pandangan, pertimbangan, atau pendapat pribadi tentang pesan yang disampaikannya dalam interaksi (Saragih, 2006). Melalui modalitas, sikap penutur dapat ditentukan dengan membuat perbedaan apakah tuturan yang diprodukasi penutur berupa proposal atau proposisi. Tuturan yang diproduksi oleh penutur berupa proposal jika klausa tersebut berkenaan dengan informasi baik berupa pernyataan maupun pertanyaan, sedangkan berupa proposal jika klausa tersebut berkenaan dengan barang dan jasa baik berupa perintah maupun tawaran(Wiratno, 2018).

Secara garis besar berdasarkan jenisnya, modalitas terbagi atas (1) modalisasi yang merupakan pendapat atau pertimbangan pribadi pemakaian bahasa terhadap proposisi, dan modulasi yang merupakan pendapat atau pertimbangan pribadi terhadap proposal. Modalisasi terdiri atas probabilitas "kemungkinan" dan usuality "keseringan" sedangkan modulasi terdiri atas obligasi "keharusan" dan inklinasi "kecenderungan". Modalisasi 'kemungkinan' menunjukkan bahwa penutur mengungkapkan penilaian tentang kemungkinan terjadinya atau keberadaan sesuatu. 'Kemungkinan' mengacu pada komitmen penutur terhadap pernyataannya yang terletak antara posisi positif dan negatif. Modalisasi 'keseringan' menunjukkan bahwa penutur mengekspresikan penilaian tentang frekuensi terjadinya atau keberadaan sesuatu. Modulasi 'keharusan' terkait dengan keinginan atau harapan penutur agar mitra tutur melakukan suatu aktivitas. 'Keharusan' tidak hanya melibatkan keadaan internal atau mental penutur tetapi juga pengaruh tekanan luar. Modulasi 'kecenderungan' mengacu pada keinginan/kesediaan atau kecenderungan emosi penutur melakukan suatu keinginan. Berdasarkan nilai, yakni tingkat kemungkinan terjadi atau tingkat kedekatannya terhadap polar 'ya' atau 'tidak', masing-masing 'kemungkinan', 'keseringan', 'keharusan', dan 'kecenderungan' dapat digolongkan ke dalam tiga tingkat: tinggi yakni aksi yang paling dekat ke polar 'ya' dan paling mungkin terjadi, tingkat rendah yang paling dekat ke polar 'tidak' dan paling tidak mungkin terjadi, dan tingkat menengah antara tingkat tinggi dan rendah.

Dari uraian tersebut, penulis berasumsi bahwa kekurangyakinan dan ketidaktahuan pembicara akan suatu informasi memengaruhi pemilihan modalitas yang digunakan. Dengan demikian, penelitian ini menawarkan satu langkah pengidentifikasian karakteristik berita hoaks dengan mengkaji jenis dan nilai modalitas yang digunakan.Penelitian terkait penggunaan modalitas telah lama menarik minat banyak peneliti. Beberapa penelitian sebelumnya menggunakan 


\section{9 | JURNAL ILMU BUDAYA}

Volume 8, Nomor 1, Juni 2020

modalitas untuk menilai tingkat komitmen calon presiden dalam debat pemilihan presiden seperti yang dilakukan oleh Abdul Azis Faradi (2015), dan Irma Setiawan (2017). Modalitas juga digunakan untuk melihat ekspresi gramatikal dari editorial surat kabar seperti yang dilakukan oleh Alireza Bonyadi (2011) dan Saba Sadia (2019). Namun, belum ada penelitian terkait penggunaan modalitas terhadap teks berita hoaks. Hal ini yang kemudian menjadi kebaruan dari penelitian ini.

\section{METODE}

Penelitian ini merupakan penelitian kualitatif dengan menggunakan metode deskriptif dan pendekatan yang digunakan dalam penelitian ini adalah pendekatan linguistic sistemik fungsional (LSF). LSF mengkaji dengan konteks yang berbeda tidak hanya berkaitan dengan tata bahasa, tetapi mencakup seluruh kompleksitas semiotik bahasa dalam konteks social (Gusnawaty et al., 2017). Dalam penelitian ini, data yang dideskripsikan berupa modalitas dalam teks berita hoaks. Deskripsi tersebut berupa jenis modalitas terdiri atas 'kemungkinan', 'keseringan', 'keharusan', dan 'kecenderungan'; nilai modalitas yang digolongkan ke dalam tiga tingkat yakni tinggi, menengah, dan rendah; serta orientasi modalitas yang terdiri atas sifat modalitas berupa subjektif dan objektif serta manifestasi modalitas berupa eksplisit dan implisit. Metode deskriptif kualitatif ini didukung dengan metode kuantitatif karena menggunakan analisis statistik sederhana. Metode kuantitatif digunakan untuk mendukung analisis statistik deskriptif dengan melihat persentase kemunculan modalitas dalam berita hoaks. Sumber data penelitian ini, ialah Laporan Hoaks Pileg dan Pilpres Subdit Pengendalian Konten Internet Periode Agustus 2018 oleh Kementerian Komunikasi dan Informasi Republk Indonesia. Terdapat 74 klausa dari 11 berita hoaks pada periode tersebut. Langkah pertama dalam penelitian ini adalah, mengumpulkan klausa yang mengandung modalitas dari teks berita hoaks tersebut. Langkah kedua mengidentifikasi klausa modalitas berdasarkan jenis, nilai, dan orientasi modalitas. Langkah ketiga, menghitung persentase kemunculan modalitas dalam teks berita hoaks.

\section{HASIL DAN PEMBAHASAN}

Laporan Hoaks Pileg dan Pilpres Subdit Pengendalian Konten Internet Periode Agustus 2018 oleh Kementerian Komunikasi dan Informasi Republik Indonesia terdiri atas 11 berita hoaks dengan total jumlah klausa sebanyak 74 klausa. Dari total 74 klausa tersebut, sebanyak 35 klausa mengandung modalitas atau sebanyak $47.30 \%$ dan terdapat 47 penanda modalitas atau sebanyak $63.51 \%$. Secara lebih rinci, dapat dilihat pada gambar 1 berikut. 


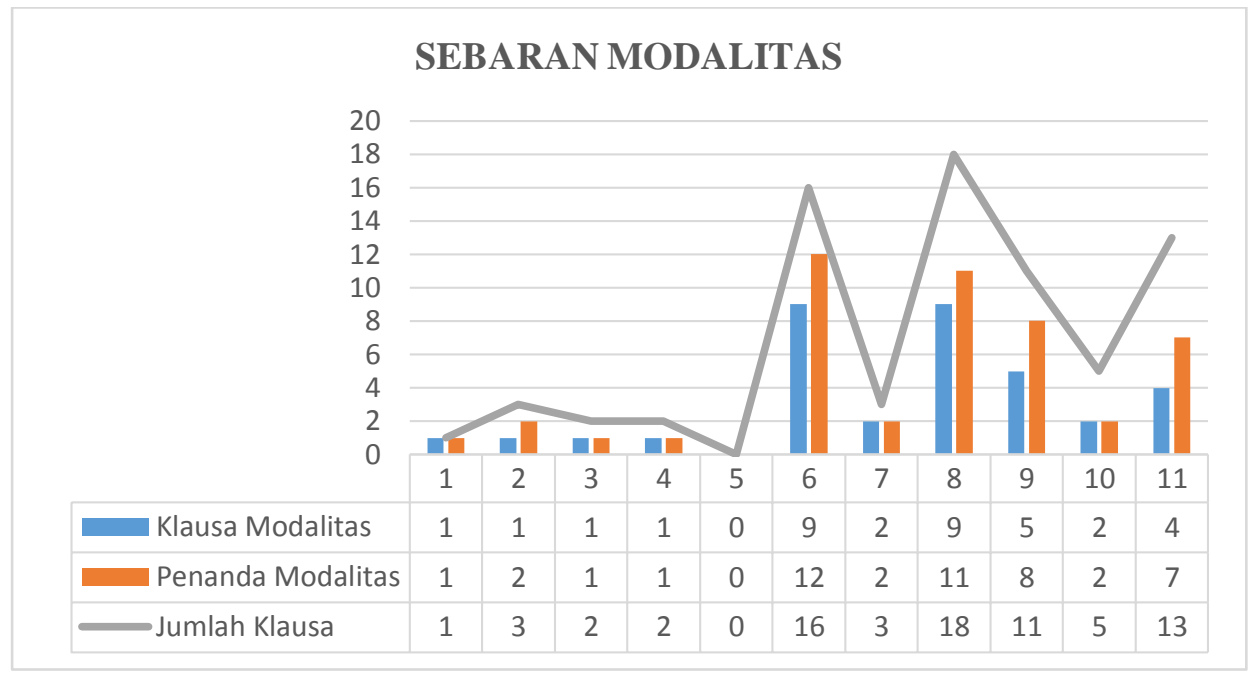

Gambar 1. Sebaran Jumlah Modalitas

a. Jenis Modalitas

Secara garis besar, modalitas terdiri atas dua jenis, yaitu (1) Modalisasi (modalization) yang merupakan pendapat atau pertimbangan pribadi pemakaian bahasa terhadap proposisi, dan (2) Modulasi (modulation) yang merupakan pendapat atau pertimbangan pribadi terhadap proposal. Pertimbangan pribadi terhadap proposal dapat berupa 'kemungkinan' dan 'keseringan' sedangkan pertimbangan pribadi terhadap proposal dapat berupa 'keharusan' dan 'kecenderungan'. Hasil identifikasi jenis modalitas dari total 11 berita hoaks tersebut menunjukkan modulasi lebih dominan digunakan dari modalisasi meskipun perbedaan sangat tipis.

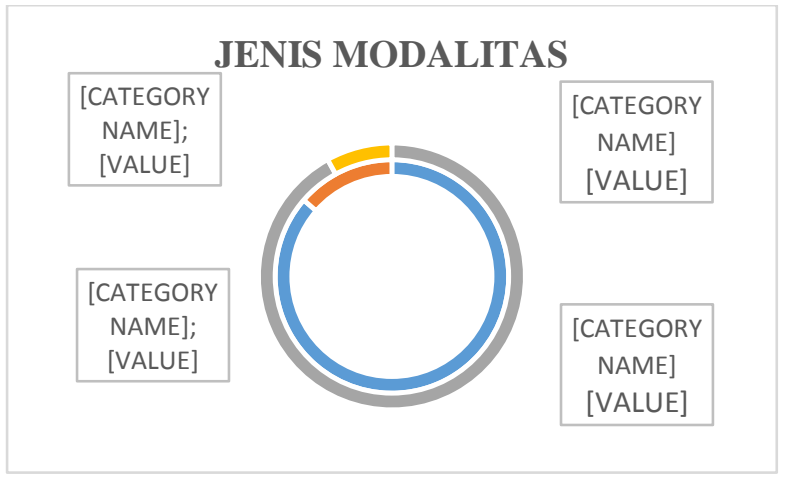

Gambar 2. Sebaran Jenis Modalitas
Berdasarkan data pada gambar 2, terlihat jumlah penggunaan modalisasi dan modulasi yang tidak jauh berbeda. 'Kemungkinan' sebagai bentuk modalisasi dan 'keharusan' sebagai bentuk modulasi mendominasi dalam teks berita hoaks dibandingkan modalisasi 'keseringan' dan modulasi 'kecenderungan'.

Modalisasi

'kemungkinan' digunakan sebanyak 19 kali atau $25.68 \%$ sedangkan modalisasi 'keseringan' muncul sebanyak 3 kali atau $4.05 \%$. Jika diakumulasikan, penanda modalitas modalisasi digunakan sebanyak 21 kali atau $29.73 \%$. Pada penelitian ini terdapat beberapa contoh modalitas modalisasi yang ditemukan dalam data adalah sebagai berikut.

(1) Dalam sidang tersebut akan dihadiri oleh Majelis Hakim Mahkamah Konstitusi

(2) Dia juga sempat mengatakan Prabowo di mata Gus Dur adalah sosok yang ikhlas kepada bangsa

Pada teks (1) terdapat penggunaan kata akan yang merupakan penanda modalitas modalisasi 'kemungkinan'. Pada teks (2) terdapat penggunaan kata sempat yang merupakan penanda modalitas 'keseringan' 


\begin{abstract}
Terkait modulasi, penanda modulasi keharusan digunakan sebanyak 23 kali atau $31.08 \%$ sedangkan penanda modalisasi kecenderungan hanya digunakan sebanyak 2 kali atau $2.70 \%$. Jika diakumulasikan, penanda modalitas modulasi digunakan sebanyak 25 kali atau $33.78 \%$. Pada penelitian ini terdapat beberapa contoh modalitas modalisasi yang ditemukan dalam data adalah sebagai berikut.
\end{abstract}

(3) "Kita juga harus berdaulat secara ekonomi, politik dan juga budaya."

(4) "Kalau Pak Prabowo sahabatnya Gus Dur, Gus Dur pernah katakan kalau mau cari orang ikhlas pada bangsa ya Prabowo.

Pada teks (3) terdapat penggunaan kata harus yang merupakan penanda modalitas modulasi 'keharusan'. Pada teks (4) terdapat penggunaan kata mau yang merupakan penanda modulasi 'kecenderungan'

Penggunaan modalitas baik yang berjenis modalisasi maupun modulasi menunjukkan bahwa karakteristik berita hoaks yang berisi proposisi yang salah kemudian diikuti proposal agar pembaca membenarkan informasi yang disampaikan meskipun informasi tersebut belum tentu terjadi.

Hasil tersebut berbeda dengan temuan Bonyadi (2011) dan Saba Sadia (2019) yang mengkaji penggunaan modalitas pada editorial dari dua surat kabar. Bonyadi membandingkan surat kabar The New York Times dengan surat kabar Tehran Times dan menemukan bahwa editorial The New York Times beranjak dari gagasan utama 'apa yang akan terjadi' sedangkan editorial Tehran Times beranjak dari gagasan utama 'apa yang harus dilakukan'(Bonyadi, 2011). Hal ini mengindikasikan editorial The New York Times bermain pada tataran modalisasi 'kemungkinan' sedangkan editorial Tehran Times bermain pada tataran modulasi 'keharusan'. Sejalan dengan Bonyadi, Sadia (2019) juga membandingkan editorial dua surat kabar Pakistan yaitu The News dan The Daily Dawn. Hasilnya pun tidak berbeda dengan hasil temuan Bonyadi bahwa editorial The News beranjak dari gagasan utama 'apa yang akan terjadi' atau bermain pada tataran modalisasi sedangkan editorial The Daily Dawn beranjak dari gagasan utama 'apa yang harus dilakukan' atau bermain pada tataran modulasi (Sadia \& Ghani, 2018).

Persamaan objek penelitian ini dengan penelitian terdahulu bahwa berita hoaks dan editorial, keduanya berupa asumsi pribadi penulis, tetapi penggunaan modalitasnya berbeda. Pada kedua penemuan tersebut terlihat bahwa informasi yang beranjak dari asumsi pribadi penulis dalam bentuk editorial hanya menggunakan salah satu dari dua jenis modalitas secara umum, yakni modalisasi atau modulasi. Berberda dengan teks berita hoaks, penggunaan modalisasi dan modulasinya hampir sama. Hal ini karena tujuan dari berita hoaks dan editorial yang berbeda meskipun keduanya berupa pendapat pribadi penulis.

b. Nilai Modalitas

Nilai atau derajat modalitas ditentukan dari kedekatannya terhadap polar. Semakin dekat modalitas yang digunakan terhadap polar positif, semakin tinggi nilai atau derajatnya. Demikian juga modalitas yang memiliki kedekatan terhadap polar negatif dikategorikan sebagai modalitas derajat rendah sedangkan nilai modalitas yang netral dikategorikan sebagai modalitas derajat menengah. Data penggunaan modalitas berdasarkan nilainya dapat dilihat pada tabel 3 . 


\section{2 | JURNAL ILMU BUDAY A}

Volume 8, Nomor 1, Juni 2020

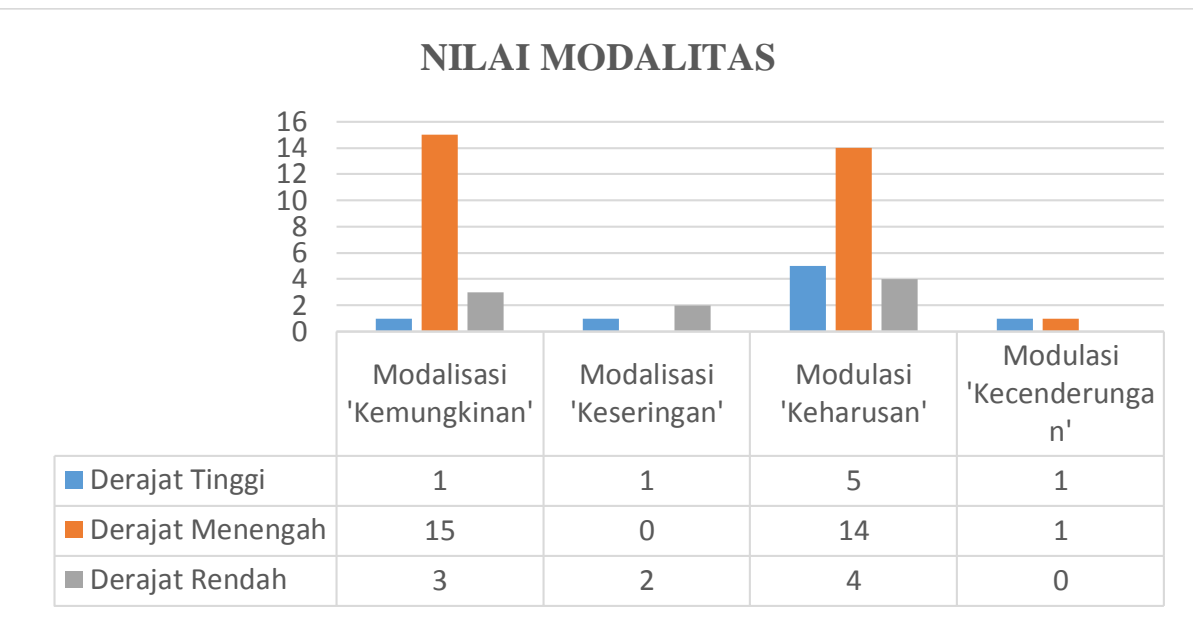

Gambar 3. Sebaran Nilai Modalitas

Berdasarkan nilai, terdapat dua modalitas yang dominan yaitu modalisasi 'kemungkinan' derajat menengah sebesar $20.27 \%$ dan modulasi 'keharusan' derajat menengah sebesar $18.92 \%$. Jenis modalitas yang tidak ditemukan dalam teks berita hoaks adalah modalisasi 'keseringan' derajat menengah dan modulasi 'kecenderungan' derajat rendah. Jenis modalitas yang paling minim kemunculannya adalah modalisasi 'kemungkinan' derajat tinggi, modalisasi 'keseringan' derajat tinggi, modulasi 'kecenderungan' derajat menengah hingga tinggi yang masingmasing sebesar $1.35 \%$ disusul modalisasi 'keseringan' derajat rendah sebesar 2.70\%, modalisasi 'kemungkinan' derajat rendah sebesar $4.05 \%$, modulasi 'keharusan' derajat rendah sebesar $5.41 \%$ dan modulasi 'keharusan' derajat tinggi sebesar $6.76 \%$ '

Modalisasi 'kemungkinan' derajat menengah yang mendominasi jenis modalisasi lainnya menggunakan penanda modalitas "akan, bakal, insyaAllah, dan mungkin" yang mengindikasikan bahwa kejadian tersebut belum terjadi. Berikut contoh penggunaan penanda modalitas modalisasi 'kemungkinan' derajat menengah yang terdapat dalam data teks berita hoaks.

(5) Pada Pilpres 2019 Prabowo akan maju berpasangan dengan Sandiaga Uno dan sudah menyambangi Ketum PBNU KH Said Aqil Siroj di kantornya.

(6) "InsyaAllah lagi disiapkan kartu anggota NU (Nahdlatul Ulama) untuk Pak Prabowo," kata Said Aqil

Pada teks (5) terdapat penggunaan penanda modalisasi 'kemungkinan' derajat menengah berupa kata akan yang artinya kejadian tersebut belum terjadi. Hal ini mengindikasikan posisi informasi tersebut berapa pada posisi netral antara polar positif dan polar negatif. Dengan kata lain, kemungkinan terjadinya dan tidak terjadinya, seimbang. Hal ini menunjukkan sikap pembuat maupun penyebar berita hoaks tidak begitu meyakini kebenaran informasi yang disampaikan.

Pada teks (6) terdapat penggunaan kata insyaAllah sebagai penanda modalisasi 'kemungkinan' derajat menengah. Kata insyaAllah secara implisit menunjukkan ekspresi penutur dalam mengaktualisasikan peristiwa. Penutur seolah telah memastikan peristiwa tersebut akan terjadi, tetapi tidak menutup kemungkinan adanya 
faktor penghambat yang dapat menyebabkan peristiwa tersebut tidak menjadi kenyataan. Dengan demikian, peristiwa tersebut berada dalam posisi netral antara polar positif dan polar negatif.

Jenis modalitas yang juga mendominasi teks berita hoaks adalah modulasi 'keharusan' derajat menengah sebesar $18.92 \%$. Modulasi 'keharusan' derajat menengah direalisasikan menggunakan penanda modalitas share, klik bagikan, selamatkan, atau kata-kata yang mencakup makna kausalitas. Berikut contoh penggunaan penanda modalitas modulasi 'keharusan' derajat menengah yang terdapat dalam data teks berita hoaks.

(7) Tunjukkan Kesalahan Pak Jokowi.

(8) Mari kita doakan semoga tidak ada banyak korban lagi .

Pada teks (7) terdapat verba perintah tunjukkan sebagai penanda modulasi 'keharusan' derajat menengah sedangkan pada teks (8) terdapat interjeksi mari dan adverbial semoga yang juga berupa penanda modulasi 'keharusan' derajat menengah. Pemilihan modulasi 'keharusan' derajat menengah mengindikasikan pembuat atau penyebar berita hoaks berharap pembaca melakukan apa yang diinginkan dalam bentuk ajakan bukan keharusan. Umumnya, suatu keharusan atau perintah dikeluarkan berdasarkan urgensi peristiwa tersebut sehingga dominansi penggunaan modulasi 'keharusan' derajat menengah mengindikasikan bahwa peristiwa tersebut belum tentu benar.

Terkait penggunaan modulasi 'keharusan', hasil penelitian ini sejalan dengan penelitian Abdul Azis Faradi (2015) dan Irma Setiawan (2017) yang menyatakan bahwa dalam debat pemilihan presiden periode 2014-2019, kedua kandidat dominan menggunakan 'keharusan' derajat menengah hingga derajat tinggi untuk mempertegas visi misinya agar meyakinkan masyarakat dalam menentukan pilihan ((Faradi, 2019); (Setiawan, 2018)). Penggunaan 'keharusan' derajat menengah yang dominan mengindikasikan para kandidat presiden tidak mampu memastikan realisasi dari semua janji yang diucapkan sehingga janji yang tidak terealisasi dianggap kebohongan oleh masyarakat.

Seseorang membuat berita hoaks bukan tanpa tujuan, melainkan mereka memang memiliki kepentingan dari hal tersebut misalnya untuk memeroleh keuntungan finansial hingga keinginan untuk mengacaukan situasi. Namun, bagi penyebar berita hoaks sebagian besar dilakukan dengan latar belakang ketidakmampuan mengidentifikasi berita hoaks sehingga diperlukan upaya peningkatan literasi masyarakat dalam mengidentifikasi berita hoaks salah satunya melalui analisis modalitas. Dilihat dari pemilihan modalitas yang digunakan dalam teks berita hoaks terkait pemilihan legislatif dan pemilihan presiden, tampak bahwa berita hoaks mempunyai karakteristik yang sebenarnya dapat diidentifikasi sehingga pembaca memiliki pertimbangan sebelum meneruskan berita tersebut. Adapun karakteristik berita hoaks yaitu suatu teks berita hoaks dominan menggunakan kata-kata yang merealisasikan modalitas baik 'kemungkinan', 'keseringan', 'keharusan', dan 'kecenderungan'. Dari keempat jenis modalitas tersebut, modalitas 'kemungkinan' dan 'keharusan' yang paling banyak digunakan. Artinya, informasi yang disajikan dalam teks berita hoaks adalah informasi yang masih berupa kemungkinan dan ajakan untuk meyakini seolah kemungkinan tersebut benar terjadi. Adapun informasi yang 
masih bersifat kemungkinan tersebut direalisasikan dalam penanda modalitas seperti memastikan, akan, insyaAllah, bakal, mungkin, menurut, dan merasa. Dari penanda modalitas 'kemungkinan' tersebut, akan yang kemunculannya paling banyak. Kata akan, mungkin, bakal, dan insyaAllah sebagai penanda modalitas 'kemungkinan' memiliki derajat menengah yang artinya tingkat kedekatannya dengan polaritas berada ditengah. Hal ini mengindikasikan bahwa informasi tersebut kemungkinan terjadinya dan kemungkinan tidak terjadinya seimbang.

Selain berupa kemungkinan, berita hoaks didominansi dengan permintaan, baik berupa perintah, ajakan, maupun izin. Hal ini terlihat dari pengguanaan penanda modulasi 'keharusan'. Katakata yang berupa verba perintah, permohonan, ajakan, harapan, izin, larangan atau keharusan dapat digunakan pembaca sebagai indikasi awal bahwa informasi tersebut adalah hoaks. Adapun penanda modulasi 'keharusan' pada berita terkait pemilihan legislatif dan pemilihan presiden yang digunakan seperti memerintahkan, jangan, harus, minta, share, mohon, simak, ganti, mari, ayo, tunjukkan, selamatkan, tenggelamkan, beritakan, dan bisa. Dari beberapa penanda modulasi 'keharusan' tersebut, verba perintah yang paling sering digunakan. Meskipun berupa perintah, tetapi perintah yang diserukan lebih berupa ajakan dan harapan bukan keharusan. Hal ini mengindikasikan bahwa pembuat maupun penyebar berita hoaks tidak meyakini atau kurang mengetahui kebanaran informasi yang disampaikan. Sebab, sesuatu yang bersifat urgen akan diperintahkan sebagai suatu keharusan sedangkan dalam teks berita hoaks perintah tersebut lebih berupa ajakan. Ajakan atau harapan merupakan permintaan yang berada pada derajat menengah yang artinya tingkat kedekatannya dengan polaritas bersifat netral. Dengan begitu, pembaca yang diharapkan sebagai pelaku aktualisasi dapat melakukan dan dapat tidak melakukan perintah tersebut.

\section{KESIMPULAN}

Total 74 klausa dari 11 berita hoaks pada Laporan Hoaks Pileg dan Pilpres Subdit Pengendalian Konten Internet Periode Agustus 2018 oleh Kementerian Komunikasi dan Informasi Republik Indonesia dan yang mengandung modalitas sebanyak $47.30 \%$ dengan penanda modalitas sebanyak 62.16\%. Dari hasil analisis modalitas diketahui teks berita hoaks dominan menggunakan modalisasi 'kemungkinan' derajat menengah sebesar $20.27 \%$ yang mengindikasikan bahwa informasi tersebut belum tentu terjadi dan pembuat maupun penyebar berita hoaks tidak meyakini atau kurang mengetahui kebenaran informasi yang disajikan. Selain itu, karena informasi tersebut kebenarannya tidak dapat dipastikan sehingga pembuat maupun penyebar berita hoaks cenderung menggunakan 'keharusan' derajat menengah sebesar $18.92 \%$ untuk memengaruhi pembaca melakukan sesuai keinginannya. Dengan demikian, temuan ini dapat mengidentifikasi karakteristik berita hoaks yaitu 1) berita hoaks banyak menggunakan penanda modalitas dalam menyampaikan informasi. Kemunculan penanda modalitas dapat mencapai lebih dari $60 \%$ sedangkan pada teks berita yang menyajikan informasi nyata menggunakan penanda modalitas dibawah 40\%. 2) Penggunaan modulasi pada berita hoaks lebih dominan yakni $33.78 \%$ sedangkan modalisasi hanya $29.73 \%$. Hal ini menunjukkan berita hoaks lebih bersifat persuasif daripada informatif. Berbeda dengan teks berita yang menyajikan informasi nyata, 


\section{5 | JURNAL ILMU BUDAYA}

Volume 8, Nomor 1, Juni 2020
E-ISSN: 2621-5101 P-ISSN:2354-7294

Permintaan yang diungkapkan oleh penulis atau penyebar berita hoaks hanya bersifat ajakan dan harapan bukan suatu keharusan. Hal ini relevan dengan informasi yang disampaikan juga berupa informasi yang belum tentu terjadi sehingga perintah tersebut menjadi tidak urgen. Dibandinkan dengan teks berita yang menyajikan informasi nyata, modulasi 'keharusan' yang digunakan adalah derajat rendah yakni berupa izin atau pembiaran. Hal ini mengindikasikan pembuat berita dengan informasi nyata memberikan kewenangan kepada pembaca dalam menentukan sikapnya.

I. M. (2014). ( Third Edition ).

Sadia, S., \& Ghani, M. (2018). Modality in Editorials of Pakistani English Newspapers: A Corpus Based Study. International Journal of English Linguistics, 9(1), 144. https://doi.org/10.5539/ijel.v9n1p144 Saragih, A. (2006). Bahasa dalam Konteks sosial. Program Pascasarjana UNIMED.

Setiawan, I. (2018). System of modality on the text of Indonesian presidential candidates debate on the period of 2014 - 2019. International Journal of Social Sciences and Humanities (IJSSH), 2(1). https://doi.org/10.29332/ijssh.v2n1.12 1

Wiratno, T. (2018). Pengantar Ringkas Linguistik Sistemik Fungsional. In Pengantar Ringkas Linguistik Sistemik Fungsional (Vol. 1, Issue 1). https://doi.org/10.1017/CBO9781107 415324.004

Halliday, M. A. K., \& Matthiessen, C. M. 